\title{
Questes
}

vestes Revue pluridisciplinaire d'études médiévales

\section{Humour et trangression des interdits dans Ysaïe le Triste}

Anne-Cécile Le Ribeuz

\section{(2) OpenEdition \\ 1 Journals}

\section{Édition électronique}

URL : http://journals.openedition.org/questes/4106

DOI : 10.4000/questes.4106

ISSN : 2109-9472

Éditeur

Les Amis de Questes

\section{Édition imprimée}

Date de publication : 15 juin 2004

Pagination : 20-25

ISSN : 2102-7188

\section{Référence électronique}

Anne-Cécile Le Ribeuz, "Humour et trangression des interdits dans Ysaï le Triste», Questes [En ligne],

7 | 2004, mis en ligne le 15 janvier 2014, consulté le 28 septembre 2020. URL : http:// journals.openedition.org/questes/4106 ; DOI : https://doi.org/10.4000/questes.4106

Ce document a été généré automatiquement le 28 septembre 2020.

(c) Association des amis de «Questes » 


\title{
Humour et trangression des interdits dans Ysaïe le Triste
}

\author{
Anne-Cécile Le Ribeuz
}

NOTE DE L'ÉDITEUR

Cet article n'a pas encore fait l'objet d'une autorisation de publication.

INDEX

Mots-clés : tabou, humour, transgression, sexualité, Ysaïe le Triste, alimentation, anthropophagie, roman

Keywords : taboo, humour, transgression, sexuality, Ysaïe le Triste, food, anthropophagy, romance 